\title{
Implications of Interspecies Transmission and Diagnosis of Mycobacterium bovis Infection in Free-Ranging Common Hippopotamus (Hippopotamus amphibius)
}

\author{
Tanya Kerr ${ }^{1}$, Wynand Goosen ${ }^{1}$, Rachiel Gumbo ${ }^{1}$, Lin-Mari deKlerk-Lorist ${ }^{2}$, Oonagh \\ Pretorius $^{2}$, Peter Buss ${ }^{3}$, Léanie Kleynhans ${ }^{1}$, Konstantin Lyashchenko ${ }^{4}$, Robin Warren ${ }^{1}$, \\ Paul van Helden ${ }^{1}$, and Michele Miller ${ }^{1}$ \\ ${ }^{1}$ University of Stellenbosch \\ ${ }^{2}$ Republic of South Africa Department of Agriculture Forestry and Fisheries \\ ${ }^{3}$ South African National Parks \\ ${ }^{4}$ Chembio Diagnostic Systems Inc
}

July 20, 2020

\begin{abstract}
Bovine tuberculosis (bTB), caused by Mycobacterium bovis (M. bovis) infection, is a multi-host disease which negatively affects the wildlife industry, with adverse consequences for conservation, ecotourism, and game/wildlife sales. Although interspecies transmission has been reported between some wildlife hosts, the risk of spread in complex ecosystems is largely unknown. As a controlled disease, tools for accurate detection of $M$. bovis infection is crucial for effective surveillance and management, especially in wildlife populations. There are however, limited species-specific diagnostic tests available for wildlife. Hippopotamuses are rarely tested for M. bovis infection and infection has not previously been confirmed in these species. In this study, blood and tissue samples collected from common hippopotamus (Hippopotamus amphibius) residing in a bTB endemic area, the Greater Kruger Protected area (GKPA), were retrospectively screened to determine whether there was evidence for interspecies transmission of $M$. bovis, and to identify tools for $M$. bovis detection in this species. Using the multi-species DPP ${ }^{\circledR}$ VetTB serological assay, a bTB seroprevelance of $8 \%$ was found in hippopotamus from GKPA. In addition, the first confirmed case of $M$. bovis infection in a free-ranging common hippopotamus is reported, based on the isolation in mycobacterial culture, genetic speciation, and detection of DNA in tissue samples. Importantly, the M. bovis spoligotype (SB0121) isolated from this common hippopotamus is shared with other $M$. bovis-infected hosts in GKPA, suggesting interspecies transmission. These results support the hypothesis that $M$. bovis infection may be under recognized in hippopotamus. Further investigation is needed to determine the risk of interspecies transmission of $M$. bovis to common hippopotamus in bTB endemic ecosystems and evaluate serological and other diagnostic tools in this species.
\end{abstract}

Title: Implications of Interspecies Transmission and Diagnosis of Mycobacterium bovis Infection in FreeRanging Common Hippopotamus (Hippopotamus amphibius )

Running Title: Mycobacterium bovis infection in common hippopotamus

Authors: Tanya J. Kerr ${ }^{1 \#}$, Wynand J. Goosen ${ }^{1 \#^{*}}$, Rachiel Gumbo ${ }^{1}$, Lin-Mari de Klerk-Lorist ${ }^{2}$, Oonagh Pretorius $^{3}$, Peter E. Buss ${ }^{4}$, Léanie Kleynhans ${ }^{1}$, Konstantin P. Lyashchenko ${ }^{5}$, Robin M. Warren ${ }^{1}$, Paul D. van Helden ${ }^{1}$, Michele A. Miller ${ }^{1}$

\section{Author institutional affiliations:}

${ }^{1}$ Department of Science and Innovation-National Research Foundation Centre of Excellence for Biomedical 
Tuberculosis Research; South African Medical Research Council Centre for Tuberculosis Research; Division of Molecular Biology and Human Genetics, Faculty of Medicine and Health Sciences, Stellenbosch University, PO Box 241, Cape Town 8000

${ }^{2}$ Skukuza State Veterinary Office, Department of Agriculture, Land Reform and Rural Development, Skukuza 1350, South Africa

${ }^{3}$ Bushbuckridge South State Veterinary Office, Department of Agriculture, Rural Development, Land and Environmental Affairs, Mkhuhlu, 1246, South Africa

${ }^{4}$ Veterinary Wildlife Services, South African National Parks, Kruger National Park, Private Bag X402, Skukuza, 1350, South Africa

${ }^{5}$ Chembio Diagnostic Systems, Inc., 3661 Horseblock Road, Medford, New York 11763, USA

\# joint first authors; *corresponding author

${ }^{*}$ Corresponding author: Dr Wynand J. Goosen; DSI-NRF Centre of Excellence for Biomedical Tuberculosis Research; South African Medical Research Council Centre for Tuberculosis Research; Division of Molecular Biology and Human Genetics, Faculty of Medicine and Health Sciences, Stellenbosch University, PO Box 241, Cape Town 8000, South Africa; Tel: +27 21938 9073; Fax: +27 73812 9141; E-mail: wjgoosen@sun.ac.za

\section{Summary:}

Bovine tuberculosis (bTB), caused by Mycobacterium bovis(M. bovis ) infection, is a multi-host disease which negatively affects the wildlife industry, with adverse consequences for conservation, ecotourism, and game/wildlife sales. Although interspecies transmission has been reported between some wildlife hosts, the risk of spread in complex ecosystems is largely unknown. As a controlled disease, tools for accurate detection of $M$. bovis infection is crucial for effective surveillance and management, especially in wildlife populations. There are however, limited species-specific diagnostic tests available for wildlife. Hippopotamuses are rarely tested for $M$. bovis infection and infection has not previously been confirmed in these species. In this study, blood and tissue samples collected from common hippopotamus (Hippopotamus amphibius) residing in a bTB endemic area, the Greater Kruger Protected area (GKPA), were retrospectively screened to determine whether there was evidence for interspecies transmission of $M$. bovis, and to identify tools for $M$. bovis detection in this species. Using the multi-species DPP ${ }^{\circledR}$ VetTB serological assay, a bTB seroprevelance of $8 \%$ was found in hippopotamus from GKPA. In addition, the first confirmed case of $M$. bovis infection in a free-ranging common hippopotamus is reported, based on the isolation in mycobacterial culture, genetic speciation, and detection of DNA in tissue samples. Importantly, the M. bovis spoligotype (SB0121) isolated from this common hippopotamus is shared with other M. bovis- infected hosts in GKPA, suggesting interspecies transmission. These results support the hypothesis that $M$. bovis infection may be under recognized in hippopotamus. Further investigation is needed to determine the risk of interspecies transmission of $M$. bovis to common hippopotamus in bTB endemic ecosystems and evaluate serological and other diagnostic tools in this species.

Keywords: Common hippopotamus, DPP ${ }^{\circledR}$ Vet TB Assay, GeneXpert ${ }^{\circledR}$ MTB/RIF Ultra qPCR Assay, Greater Kruger Protected Area, interspecies transmission, Mycobacterium bovis

\section{INTRODUCTION}

Bovine tuberculosis (bTB), caused by Mycobacterium bovis(M. bovis ) infection, is a multi-host disease which negatively affects the wildlife industry, with adverse consequences for conservation, ecotourism, and game/wildlife sales (Renwick, White, \& Bengis, 2007). Importantly, the presence of wildlife maintenance hosts further complicates the control of $M$. bovis infections and increases the risk of interspecies transmission, especially in multi-host systems (Brites et al ., 2018). In South Africa, this is demonstrated by ongoing outbreaks of bTB caused by spread of M. bovis from African buffaloes (Syncerus caffer ) to livestock and other wildlife species (Hlokwe, van Helden, \& Michel, 2014). Interspecies transmission of M. bovis is recognized as 
a risk for spreading disease within and between populations of susceptible hosts, therefore, accurate tools for detection in multiple species are needed for effective management of bTB.

Although M. bovis is a controlled disease, surveillance and development of diagnostic tools are often limited to livestock, with a paucity of species-specific diagnostic tests available for wildlife. For this reason, several direct detection methods are used for surveillance purposes including mycobacterial culture and Xpert ${ }^{\circledR} \mathrm{MTB} / \mathrm{RIF}$ Ultra qPCR Assay (GXU), as well as multi-species serological assays, such as the Chembio Dual Path Platform (DPP $\left.{ }^{\circledR}\right)$ Vet TB Assay (Hlokwe \& Mogano, 2020; Kerr et al ., 2020; Miller, Buss, Roos, et al ., 2019). These tests may prove useful for screening susceptible hosts from bTB endemic areas, such as the Greater Kruger Protected Area (GKPA), South Africa, to investigate interspecies transmission and risk of disease.

Common hippopotamuses (Hippopotamus amphibius ) have a wide distribution in sub-Saharan Africa but are considered vulnerable by the International Union for the Conservation of Nature (IUCN) (Lewison \& Pluháček, 2017). As a result of the difficulty and danger associated with handling this species, few studies have been undertaken to evaluate disease status, especially in free-ranging populations. For example, it is unknown whether $M$. bovis infection can be transmitted to hippopotamuses in the bTB-endemic GKPA (over 2 million hectares in size), which has an estimated 3100 hippopotamuses (Lewison \& Pluháček, 2017).

$M$. bovis infection has not previously been confirmed in any hippopotamus species, and these animals are rarely tested for bTB (Bouts, Vordermeier, Flach, \& Routh, 2009; Mann, Bush, Janssen, Frank, \& Montali, 1981; Miller \& Lyashchenko, 2015). However, in order to assess the infection risk prior to translocating animals from bTB endemic areas, it is necessary to develop tools for surveillance and diagnosis. Therefore, the aim of this project was to perform retrospective screening of blood (serum) and tissue samples (lung and lymph node) collected from common hippopotamuses in GKPA as part of a bTB surveillance project and determine the potential risk of interspecies transmission. These findings will inform management decisions and policy development for bTB in wildlife.

\section{MATERIALS AND METHODS}

2. Animals and samples:

Between 2016 and 2019, opportunistic samples were collected from 60 randomly culled free-ranging common hippopotamuses in the Kruger National Park, South Africa and adjacent private reserves included within the GKPA ( $>2$ million hectares). These culls were part of a species management plan undertaken during periods of extreme drought. The sex $($ male $=29$; female $=30$; not recorded $=1)$ and age category of each hippopotamus were recorded at the time of sampling. Individuals were categorized as adult $(\mathrm{n}=48)$; young/sub-adult $(\mathrm{n}=7)$; or juvenile $(\mathrm{n}=4)$, based on body size. The age of one individual was not recorded. Serum ( $\mathrm{n}=49$ animals) and post-mortem tracheobronchial lymph node and lung samples $(\mathrm{n}=50$ animals $)$ were collected by state veterinary personnel and stored at $-20^{\circ} \mathrm{C}$ prior to testing. Not all sample types were available from every individual. Ethical clearance to retrospectively screen these samples was obtained from the Stellenbosch University Research Ethics Committee (Protocol \#: SU-ACU-9086; SU-ACU-10933), and Section 20 approval was granted by the South African Department of Agriculture, Forestry, and Fisheries (DAFF Section 20: 12/11/1/7/2). All testing was performed as part of this research project and not in official diagnostic laboratories for controlled animal diseases.

Dual Path Platform $\left(\mathrm{DPP}^{\circledR}\right)$ Vet TB Assay

All sera were screened for antibodies to mycobacterial antigens using a multi-species rapid serological test, the DPP ${ }^{\circledR}$ Vet TB Assay (Chembio Diagnostic Systems, Inc., Medford, NY, USA), according to the manufacturer's instructions. Antibody binding was measured using a DPP ${ }^{\circledR}$ optical reader (Chembio) and reflectance reported in relative light units (RLU). Reactivity of serum to either test line 1 (antigen MBP83) and/or test line 2 (antigen CFP-10/ESAT-6) above the visual cut-off value (RLU [?] 5) was considered test-positive (Greenwaldet al ., 2009). Test results were considered valid only if the control line could be visualized. 
1. Mycobacterial culture

2. Tissue homogenisation

Tissue homogenisation and mycobacterial culture was performed under Biosafety Level 3 (BSL-3) conditions. Briefly, approximately 10 grams of tissue (from either tracheobronchial lymph nodes or lung samples depending on each individual hippopotamus sample availability) were homogenized in $50 \mathrm{~mL}$ skirted falcon tubes (Becton Dickinson, Franklin Lakes, NJ, USA) containing eight $4.8 \mathrm{~mm}$ metal beads and $4 \mathrm{~mL}$ sterile BBL MycoPrep Phosphate Buffer $\left(\mathrm{PO}_{4}\right.$ buffer) (Becton Dickinson) using a Bullet Blender ${ }^{(\mathrm{r})} 50$ (Next Advance, Averill Park, NY, USA) for 15 min at maximum speed. Following homogenisation, remaining intact tissue was discarded and tissue homogenates split in equal volumes for downstream testing with mycobacterial culture and the GXU assay (Cepheid, Sunnyvale, CA, USA).

Culture and genomic speciation

Following homogenisation, $2 \mathrm{~mL}$ BD BBL MycoPrep (Becton Dickinson) was added to $2 \mathrm{~mL}$ of each tissue homogenate sample and incubated for 15 minutes at room temperature. Thereafter, samples were neutralized with $15 \mathrm{~mL} \mathrm{PO}_{4}$ buffer. All samples were centrifuged for $20 \mathrm{~min}$ at $3000 \mathrm{rcf}$ and the supernatant decanted. Each pellet was resuspended in $1 \mathrm{~mL} \mathrm{PO}_{4}$ buffer and $500 \mu \mathrm{l}$ of this suspension was transferred to a Mycobacteria Growth Indicator Tube (MGIT) containing $800 \mu \mathrm{l}$ of BD BACTEC MGIT 960 Supplement and incubated in a BACTEC MGIT 960 Mycobacterial Detection System for at least 56 days (all Becton Dickinson). Cultured bacterial isolates were genetically speciated by genomic regions of difference PCR (Warrenet al ., 2006), 16S rRNA sequencing (Leclerc, Haddad, Moreau, \& Thorel, 2000) and spoligotyping (Kamerbeek et al ., 1997). The spoligotype of the isolate from this study was authenticated by comparing the observed spoligotype pattern to known spoligotypes in theMycobacterium bovis Spoligotype Database (https://www.mbovis.org/database.php; Smith \& Upton, 2012).

Xpert ${ }^{\circledR}$ MTB/RIF Ultra Assay (GXU)

As a rapid ancillary method to mycobacterial culture, the GXU assay was used to detect Mycobacterium tuberculosis complex (MTBC) DNA within tissue homogenates (Chakravorty et al., 2017). Briefly $1.3 \mathrm{~mL}$ of the Xpert ${ }^{\circledR}$ Sample Lysis Reagent (Cepheid) was added to each $700 \mu$ l tissue homogenate aliquot under BSL3 conditions. Samples were vortexed for 10 seconds, incubated for 10 minutes at room temperature, mixed again by vortexing for another 10 seconds, and incubated for a final 5 minutes for optimal microbial DNA release and bacilli inactivation. The total volume of $2 \mathrm{~mL}$ was transferred to a GXU Cartridge (Cepheid) and analysed per manufacturer's instruction (Cepheid, Alternative Specimen Testing).

\section{RESULTS}

Of the 49 serum samples tested in this study, sera from four hippopotamuses were positive using the $\mathrm{DPP}^{\circledR}$ Vet TB Assay (Table 1), resulting in a bTB seroprevalence of $8 \%$ (95\% CI $3-19 \%)$ in the tested population. The RLU values for the four DPP ${ }^{\circledR}$-positive hippopotamuses were between 0 and $14.3 \mathrm{RLU}$ for test line 1 (MBP83) and between 0 and 18.1 RLU for test line 2 (CFP-10/ESAT-6), with only one individual (SU ID: 19/142) reactive to both test lines (Table 1). Serum collected from the $M$. bovisculture-positive hippopotamus (SU ID: 19/169) had antibodies to CFP-10/ESAT-6 only (Table 1).

Using the GXU assay, MTBC DNA was detected (LOW) in the tissue homogenates from two hippopotamuses (SU IDs: 19/169 and 19/170), with TRACE amounts in an additional three animals (Table 2). M. boviswas cultured from both the lung and thoracic lymph node samples collected from a single hippopotamus (SU ID: 19/169; Table 2). Further PCR-based speciation confirmed the strain present in both the lung and thoracic lymph node samples was spoligotype SB0121 (Table 3). The raw data that support the findings of this study are available from the corresponding author upon reasonable request.

\section{DISCUSSION:}

The findings of this retrospective study confirm that common hippopotamus can be infected with M. bovis. This was verified by the isolation of bacilli from lung and thoracic lymph node tissue collected from a 
single free-ranging adult male hippopotamus. Significantly, the M. bovis strain (SB0121) isolated from the hippopotamus in the GKPA is commonly found in this region and has been previously isolated in several wildlife species including African buffalo (Syncerus caffer), Chacma baboon (Papio ursinus), greater kudu (Tragelaphus strepsiceros), leopard (Panthera pardus ) and African lion (Dippenaar et al ., 2017; Michelet al ., 2009). African buffaloes are considered a reservoir host for bTB in this ecosystem and interspecies spillover to livestock and other wildlife has been reported (Hlokwe et al ., 2014; Musoke, Hlokwe, Marcotty, du Plessis, \& Michel, 2015; Renwick etal ., 2007). Therefore, buffaloes are considered the most likely source of infection. Since studies of wild boar populations have demonstrated that $M$. bovis can be spread through environmental contamination around waterholes to other species (Naranjo, Gortazar, Vicente, \& de la Fuente, 2008), it is speculated that the hippopotamus was indirectly infected.

Although mycobacterial culture of post-mortem tissues and speciation of bacterial isolates remain the gold standard method for the confirmation of $M$. bovis infection in wildlife, this method is limited by the ability to acquire tissue samples as well as suboptimal sensitivity of culture (de la Rua-Domenech et al ., 2006). Therefore, other methods are needed for accurate detection of infection. In the case of the $M$. bovis cultureconfirmed hippopotamus in this study, mycobacterial specific antibodies were detected, suggesting that the DPP ${ }^{\circledR}$ Vet TB assay may be useful for indirect detection of MTBC infection in this species. The mycobacterial culture results were also consistent with the positive GXU results, which were obtained directly from tissue homogenates. Although culture confirmed infection in only one hippopotamus, there were three additional animals with seropositive results, suggesting that these animals may have been previously infected. Overall, using mycobacterial culture, GXU, and the serological test, there were 7 out of 60 hippopotamuses that had evidence of $M$. bovis infection, suggesting prevalence could be higher in GKPA than previously expected.

A positive antibody response to bTB specific antigens MPB83 and/or CFP-10/ESAT-6 was observed in four hippopotamuses, including one culture-positive individual screened using the DPP ${ }^{\circledR}$ Vet TB Assay, resulting in an estimated bTB seroprevalence of $8 \%$. The DPP ${ }^{\circledR}$ Vet TB Assay is not a host species-specific assay, and several species including African and Asian elephants (Loxodonta africana; Elephas maximus ), African lions (Panthera leo ), cheetah (Acinonyx jubatus) and common warthogs (Phacochoerus africanus) with cultureconfirmed TB have previously been shown to produce antibody responses to MPB83 and/or CFP-10/ESAT-6 (Greenwald et al ., 2009; Kerr et al ., 2019, 2020; Lyashchenko et al ., 2006; Miller, Buss, Sylvester, et al ., 2019; Miller et al ., 2016; Roos et al ., 2016). The association between seropositivity and culture-confirmed MTBC infection suggests that rapid antibody assays might be useful as an ante-mortem screening test for $M$. bovis infection in hippopotamuses.

Furthermore, low concentrations of MTBC DNA were detected in the tissue homogenates from two hippopotamuses using GXU. While the GXU assay cannot distinguish between members of the MTBC, it is still highly specific to MTBC, based on the simultaneous detection of MTBC-specific multicopy genes IS6110 and IS1081 (Chakravorty et al ., 2017). However, like most qPCR assays, it also cannot distinguish between live or dead mycobacteria bacilli (Theron et al ., 2014). However, as an ancillary method to culture, this DNA test is a strong indicator that if live mycobacteria are present, it is at the same quantity of DNA detected in the sample (Chakravorty et al ., 2017). Usually, a positive mycobacterial culture result can be anticipated from a positive GXU sample, as previously observed in post-mortem tissue samples collected from an M. bovis -infected cheetah (Kerr et al ., 2020). Thus, a positive PCR test result strongly supports the subsequent diagnosis of $M$. bovisinfection based on culture.

Limitations associated with this study include sample acquisition and the nature of the samples themselves. Firstly, all samples used in this study were acquired opportunistically through culling. Culling usually targets specific age groups, sexes or family groups resulting in a sampling approach biased towards certain demographics. In this study, family groups were targeted to reduce the number of individuals within a pod. Secondly, long term storage of frozen tissue samples (since 2016) may have affected the number of viable mycobacteria present in some of these tissues. Finally, unlike tissue samples acquired from other species, the tissue samples from hippopotamuses have a very high fat content which affected tissue homogenisation and 
therefore, downstream application of GXU and mycobacterial culture. During initial sample processing, we observed several invalid GXU results. For subsequent samples, we increased the initial volume of $\mathrm{PO}_{4}$ buffer (for tissue homogenization) from 2 to $4 \mathrm{~mL}$. Therefore, additional optimisations of mycobacterial culture for use in this species may further improve the utility of this assay.

Hippopotamus sampling occurred during a prolonged drought in GKPA, therefore, the presence of artificial waterholes and increased density of hippopotamus as well as use by other $M$. bovis hosts such as buffaloes in this area may have contributed to risk of infection and should be investigated further. Based on a single culture confirmed case, the susceptibility to infection, potential progression to disease, and route of infection in hippopotamus remain unknown. However, since no obvious clinical signs or macroscopic pathology were observed in this cohort of hippopotamuses, there is no evidence that this species develops active disease. Further research should therefore be performed to investigate infected hippopotamus, especially in endemic populations, and continued abattoir surveillance should also be conducted when the opportunities arise.

In conclusion, the results reported here demonstrate the utility of $\mathrm{DPP}^{\circledR}$ VetTB assay, GXU, and mycobacterial culture for detecting $M$. bovis infection in common hippopotamus. Our findings suggest potential tools for screening this species for bTB, which will aid in diagnosis in zoo hippopotamus and surveillance in free-ranging populations.

\section{ACKNOWLEDGEMENTS}

The authors wish to acknowledge the Skukuza State Veterinary Office, Department of Agriculture, Land Reform and Rural Development (DALRRD), and Bushbuckridge South State Veterinary Office, Department of Agriculture, Rural Development, Land and Environmental Affairs, for providing the samples. The authors also wish to thank Ian Olivier, Dave Varty, and Cepheid for supporting this research. Financial support for this research was provided by the South African Medical Research Council (SAMRC) Centre for Tuberculosis Research, the National Research Foundation (NRF) South African Research Chair Initiative (SARChI grant number 86949), the Harry Crossley Foundation (HCF), and the Sabie Sand Wildtuin Nature Conservation Trust (NTC). Funding to TJK was provided through NRF SAMRC CTB Postdoctoral Fellowship. Funding to WJG was provided by National Geographic Society Explorer Grant (S006337). Opinions expressed, and conclusions arrived at, are those of the authors and are not necessarily to be attributed to the funders.

\section{CONFLICT OF INTEREST}

The authors report no conflict of interest.

\section{REFERENCES}

Bouts, T., Vordermeier, M., Flach, E., \& Routh, A. (2009). Positive skin and serologic test results of diagnostic assays for bovine tuberculosis and subsequent isolation of Mycobacterium interjectum in a pygmy hippopotamus (Hexaprotodon liberiensis ).Journal of Zoo and Wildlife Medicine , 40 (3), 536-542.

Brites, D., Loiseau, C., Menardo, F., Borrell, S., Boniotti, M. B., Warren, R., Gagneux, S. (2018). A new phylogenetic framework for the animal-adapted Mycobacterium tuberculosis complex. Frontiers in Microbiology , $9,1-14$.

Chakravorty, S., Simmons, A. M., Rowneki, M., Parmar, H., Cao, Y., Ryan, J., Alland, D. (2017). The new Xpert MTB/RIF Ultra: Improving detection of Mycobacterium tuberculosis and resistance to Rifampin in an assay suitable for point-of-care testing. MBio , 8 (4), 1-12.

de la Rua-Domenech, R., Goodchild, A. T., Vordermeier, H. M., Hewinson, R. G., Christiansen, K. H., \& Clifton-Hadley, R. S. (2006). Ante mortem diagnosis of tuberculosis in cattle: A review of the tuberculin tests, $\gamma$-interferon assay and other ancillary diagnostic techniques.Research in Veterinary Science , 81 (2), 190-210.

Dippenaar, A., Parsons, S. D. C., Miller, M. A., Hlokwe, T., Gey van Pittius, N. C., Adroub, S. A., van Helden, P. D. (2017). Progenitor strain introduction of Mycobacterium bovis at the wildlife-livestock interface 
can lead to clonal expansion of the disease in a single ecosystem. Infection, Genetics and Evolution ,51 , $235-238$.

Greenwald, R., Lyashchenko, O., Esfandiari, J., Miller, M., Mikota, S., Olsen, J. H., Lyashchenko, K. P. (2009). Highly accurate antibody assays for early and rapid detection of Tuberculosis in African and Asian elephants. Clinical and Vaccine Immunology , 16 (5), 605-612.

Hlokwe, T. M., van Helden, P., \& Michel, A. L. (2014). Evidence of increasing intra and inter-species transmission of Mycobacterium bovis in South Africa: Are we losing the battle? Preventive Veterinary Medicine , 115 (1-2), 10-17.

Hlokwe, Tiny Motlatso, \& Mogano, R. M. (2020). Utility of Xpert ${ }^{\circledR}$ MTB/RIF Ultra assay in the rapid diagnosis of bovine tuberculosis in wildlife and livestock animals from South Africa.Preventive Veterinary Medicine, 177 .

Kamerbeek, J., Schouls, L., Kolk, A., van Agterveld, M., van Soolingen, D., Kuijper, S., van Embden, J. (1997). Simultaneous detection and strain differentiation of Mycobacterium tuberculosis for diagnosis and epidemiology. Journal of Clinical Microbiology ,35 (4), 907-914.

Kerr, T. J., de Waal, C. R., Buss, P. E., Hofmeyr, J., Lyashchenko, K. P., \& Miller, M. A. (2019). Seroprevalence of Mycobacterium tuberculosis complex in free-ranging African elephants (Loxodonta africana ) in Kruger National Park, South Africa. Journal of Wildlife Diseases , 55 (4), 923-927.

Kerr, T. J., Gumbo, R., Goosen, W. J., Rogers, P., Last, R. D., \& Miller, M. A. (2020). Novel techniques for detection ofMycobacterium bovis infection in a cheetah. Emerging Infectious Diseases , 26 (3), 630-631.

Leclerc, M. C., Haddad, N., Moreau, R., \& Thorel, M. F. (2000). Molecular characterization of environmental mycobacterium strains by PCR-restriction fragment length polymorphism of hsp65 and by sequencing of hsp65, and of 16S and ITS1 rDNA. Research in Microbiology ,151 (8), 629-638.

Lewison, R., \& Pluháček, J. (2017). Hippopotamus amphibius , common hippopotamus. The IUCN Red List of Threatend Species, e.T10103A18567364.

Lyashchenko, K. P., Greenwald, R., Esfandiari, J., Olsen, J. H., Ball, R., Dumonceaux, G., Waters, W. R. (2006). Tuberculosis in elephants: antibody responses to defined antigens of Mycobacterium tuberculosis , potential for early diagnosis, and monitoring of treatment. Clinical and Vaccine Immunology , 13 (7), $722-732$.

Mann, P. C., Bush, M., Janssen, D. L., Frank, E. S., \& Montali, R. J. (1981). Clinicopathologic correlations of tuberculosis in large zoo mammals. Journal of the American Veterinary Medical Association ,179 (11), $1123-1129$.

Michel, A. L., Coetzee, M. L., Keet, D. F., Maré, L., Warren, R., Cooper, D., van Helden, P. (2009). Molecular epidemiology ofMycobacterium bovis isolates from free-ranging wildlife in South African game reserves. Veterinary Microbiology , 133 (4), 335-343.

Miller, M. A., Buss, P., Roos, E. O., Hausler, G., Dippenaar, A., Mitchell, E., van Helden, P. (2019). Fatal tuberculosis in a free-ranging African elephant and one health implications of human pathogens in wildlife. Frontiers in Veterinary Science , 6 , 1-8.

Miller, M. A., Buss, P., Sylvester, T. T., Lyashchenko, K. P., DeKlerk-Lorist, L.-M., Bengis, R., Olea-Popelka, F. (2019).Mycobacterium bovis in free-rangng lions (Panthera leo ) - evaluation of serological and tuberculin skin tests for detection of infection and disease. Journal of Zoo and Wildlife Medicine ,50 (1), 7-15.

Miller, M. A., \& Lyashchenko, K. P. (2015). Mycobacterial Infections in other zoo animals. In H. Mukundan, M. A. Chambers, W. R. Waters, \& M. H. Larsen (Eds.), Tuberculosis, Leprosy and Mycobacterial Diseases of Man and Animals: The Many Hosts of Mycobacteria (pp. 277-295). CABI, Boston, Massachusetts. 
Miller, M., Buss, P., Klerk-Lorist, L. M. De, Hofmeyr, J., Hausler, G., Lyashchenko, K., Helden, P. Van. (2016). Application of rapid serologic tests for detection of Mycobacterium bovis infection in free-ranging warthogs (Phacochoerus africanus) - implications for antemortem disease screening. Journal of Wildlife Diseases ,52 (1).

Musoke, J., Hlokwe, T., Marcotty, T., du Plessis, B. J. A., \& Michel, A. L. (2015). Spillover of Mycobacterium bovis from wildlife to livestock, South Africa. Emerging Infectious Diseases ,21 (3), 448-451.

Naranjo, V., Gortazar, C., Vicente, J., \& de la Fuente, J. (2008). Evidence of the role of European wild boar as a reservoir of Mycobacterium tuberculosis complex. Veterinary Microbiology , 127 (1-2), 1-9.

Renwick, A. R., White, P. C. L., \& Bengis, R. G. (2007). Bovine tuberculosis in southern African wildlife: A multi-species host-pathogen system. Epidemiology and Infection , 135 (4), 529-540.

Roos, E. O., Buss, P., de Klerk-Lorist, L. M., Hewlett, J., Hausler, G. A., Rossouw, L., Miller, M. A. (2016). Test performance of three serological assays for the detection of Mycobacterium bovisinfection in common warthogs (Phacochoerus africanus ).Veterinary Immunology and Immunopathology , 182 , 79-84.

Smith, N. H., \& Upton, P. (2012). Naming spoligotype patterns for the RD9-deleted lineage of the Mycobacterium tuberculosis complex; www.Mbovis.org. Infection, Genetics and Evolution, 12 (4), 873-876.

Theron, G., Zijenah, L., Chanda, D., Clowes, P., Rachow, A., Lesosky, M., ... Dheda, K. (2014). Feasibility, accuracy, and clinical effect of point-of-care Xpert MTB/RIF testing for tuberculosis in primary-care settings in Africa: A multicentre, randomised, controlled trial. The Lancet, 383 (9915), 424-435.

Warren, R. M., Gey van Pittius, N. C., Barnard, M., Hesseling, A., Engelke, E., de Kock, M., van Helden, P. D. (2006). Differentiation of Mycobacterium tuberculosis complex by PCR amplification of genomic regions of difference. The International Journal of Tuberculosis and Lung Diseases , 10 (7), 818-822.

Table 1 : Demographic information and test results for the four common hippopotamuses identified as antibody-positive by the Chembio DPP ${ }^{\circledR}$ Vet TB Assay

\begin{tabular}{|c|c|c|c|c|c|c|c|}
\hline \multirow[b]{2}{*}{$\begin{array}{l}\text { Sample } \\
\text { Number }\end{array}$} & \multirow[b]{2}{*}{$\begin{array}{l}\text { Sample } \\
\text { Year }\end{array}$} & \multirow[b]{2}{*}{ Age Class } & \multirow[b]{2}{*}{ Sex } & \multirow[b]{2}{*}{$\begin{array}{l}\text { Sampling } \\
\text { Location }\end{array}$} & \multirow{2}{*}{$\begin{array}{l}\text { Test Line } 1 \\
\text { MPB83 } \\
(\text { RLU+) }\end{array}$} & \multicolumn{2}{|c|}{ CFP10/ESATEontrol } \\
\hline & & & & & & $\begin{array}{l}6 \\
(\mathrm{RLU})\end{array}$ & $\begin{array}{l}\text { Line } \\
\text { (RLU) }\end{array}$ \\
\hline $19 / 142$ & 2019 & Adult & $\mathrm{M}$ & GKPA & 14.3 & 18.1 & 157.1 \\
\hline $19 / 158$ & 2019 & Adult & $\mathrm{F}$ & GKPA & 5.4 & 0 & 159.9 \\
\hline $19 / 169++$ & 2019 & Adult & $\mathrm{M}$ & GKPA & 0 & 8.6 & 147.4 \\
\hline $19 / 170$ & 2019 & Adult & $\mathrm{F}$ & GKPA & 5.8 & 0 & 153.1 \\
\hline+ reflective & + reflective & + reflective & + reflective & + reflective & + reflective & + reflective & + reflective \\
\hline light units & light units & light units & light units & light units & light units & light units & light units \\
\hline (RFL). & (RFL). & (RFL). & (RFL). & (RFL). & (RFL). & (RFL). & (RFL). \\
\hline $\begin{array}{l}++M . \\
\text { bovis }\end{array}$ & $\begin{array}{l}++M \\
\text { bovis }\end{array}$ & $\begin{array}{l}++M \\
\text { bovis }\end{array}$ & $\begin{array}{l}++M \\
\text { bovis }\end{array}$ & $\begin{array}{l}++M \\
\text { bovis }\end{array}$ & $\begin{array}{l}++M \\
\text { bovis }\end{array}$ & $\begin{array}{l}++M \\
\text { bovis }\end{array}$ & $++M$. \\
\hline infection & infection & infection & infection & infection & infection & infection & infection \\
\hline & & $\begin{array}{l}\text { confirmed } \\
\text { with }\end{array}$ & $\begin{array}{l}\text { confirmed } \\
\text { with }\end{array}$ & $\begin{array}{l}\text { confirmed } \\
\text { with }\end{array}$ & $\begin{array}{l}\text { confirmed } \\
\text { with }\end{array}$ & $\begin{array}{l}\text { confirmed } \\
\text { with }\end{array}$ & $\begin{array}{l}\text { confirmed } \\
\text { with }\end{array}$ \\
\hline culture & culture & culture & culture & culture & culture & culture & culture \\
\hline and PCR. & and PCR. & and PCR. & and PCR. & and PCR. & and PCR. & and PCR. & and PCR. \\
\hline$\S$ Greater & $\S$ Greater & $\S$ Greater & $\S$ Greater & $\S$ Greater & $\S$ Greater & $\S$ Greater & $\S$ Greater \\
\hline Kruger & Kruger & Kruger & Kruger & Kruger & Kruger & Kruger & Kruger \\
\hline Protected & Protected & Protected & Protected & Protected & Protected & Protected & Protected \\
\hline Area & Area & Area & Area & Area & Area & Area & Area \\
\hline (GKPA). & (GKPA). & (GKPA). & (GKPA). & (GKPA). & (GKPA). & (GKPA). & (GKPA). \\
\hline
\end{tabular}


Table 2: Demographic information and test results for the seven common hippopotamuses identified as test positive by the Chembio DPP ${ }^{\circledR}$ Vet TB Assay, Xpert ${ }^{\circledR}$ MTB/RIF Ultra qPCR assay, or mycobacterial culture

\begin{tabular}{|c|c|c|c|c|c|c|c|c|}
\hline \multirow{2}{*}{$\begin{array}{l}\text { Sample } \\
\text { Number }\end{array}$} & \multirow{2}{*}{$\begin{array}{l}\text { Sample } \\
\text { Year }\end{array}$} & \multirow[b]{2}{*}{ Age Class } & \multirow[b]{2}{*}{ Sex } & \multicolumn{2}{|l|}{ Sampling } & \multirow[b]{2}{*}{ GXU ++} & \multicolumn{2}{|c|}{ Mycobacterial } \\
\hline & & & & Location & $\mathbf{D P P}^{\circledR}+$ & & Culture & Specia \\
\hline $19 / 169$ & 2019 & Adult & $\mathrm{M}$ & GKPA§ & + & $\begin{array}{l}\text { MTBC } \\
\text { detected } \\
\text { LOW }\end{array}$ & + & $\begin{array}{l}\text { M. bovi } \\
\text { SB0121 }\end{array}$ \\
\hline $19 / 170$ & 2019 & Adult & $\mathrm{F}$ & GKPA & + & $\begin{array}{l}\text { MTBC } \\
\text { detected } \\
\text { LOW }\end{array}$ & - & \\
\hline $19 / 142$ & 2019 & Adult & $\mathrm{M}$ & GKPA & + & $\begin{array}{l}\text { MTBC } \\
\text { not } \\
\text { detected }\end{array}$ & - & \\
\hline $19 / 158$ & 2019 & Adult & $\mathrm{F}$ & GKPA & + & $\begin{array}{l}\text { MTBC } \\
\text { not } \\
\text { detected }\end{array}$ & - & \\
\hline SU9/16 & 2016 & $\begin{array}{l}\text { Sub- } \\
\text { adult }\end{array}$ & $\mathrm{F}$ & GKPA & $\mathbb{1}$ & $\begin{array}{l}\text { MTBC } \\
\text { TRACE }\end{array}$ & - & \\
\hline $16 / 136$ & 2016 & Adult & $\mathrm{F}$ & GKPA & - & $\begin{array}{l}\text { MTBC } \\
\text { TRACE }\end{array}$ & - & \\
\hline $16 / 146$ & 2016 & Adult & $\mathrm{M}$ & GKPA & - & $\begin{array}{l}\text { MTBC } \\
\text { TRACE }\end{array}$ & - & \\
\hline
\end{tabular}




\begin{tabular}{|c|c|c|c|c|c|c|c|c|}
\hline \multirow{2}{*}{$\begin{array}{l}\text { Sample } \\
\text { Number }\end{array}$} & \multicolumn{3}{|l|}{ Sample } & \multicolumn{3}{|l|}{ Sampling } & \multicolumn{2}{|c|}{ Mycobacterial } \\
\hline & Year & Age Class & Sex & Location & $\mathrm{DPP}^{\circledR}+$ & GXU++ & Culture & Speci \\
\hline +Chembio & +Chembio & + Chembio & +Chembio & -Chembio & + Chembio & +Chembio & +Chembio & +Chem \\
\hline $\mathrm{DPP}^{\circledR}$ & $\mathrm{DPP}^{\circledR}$ & $\mathrm{DPP}^{\circledR}$ & $\mathrm{DPP}^{\circledR}$ & $\mathrm{PP}^{\circledR}$ & $\mathrm{PP}^{\circledR}$ & $\mathrm{DPP}^{\circledR}$ & $\mathrm{DPP}^{\circledR}$ & $\mathrm{DPP}^{\circledR}$ \\
\hline Vet TB & Vet TB & et TB & et TB & et $\mathrm{TB}$ & et TB & et TB & et TB & et $\mathrm{TB}$ \\
\hline $\begin{array}{l}\text { Assay. } \\
++ \text { Xpert }^{(r)}\end{array}$ & $\begin{array}{l}\text { Assay. } \\
++ \text { Xpert }^{(\mathrm{r})}\end{array}$ & $\begin{array}{l}\text { Assay. } \\
++ \text { Xpert }^{(\mathrm{r})}\end{array}$ & $\begin{array}{l}\text { Assay. } \\
++ \text { Xpert }^{(\mathrm{r})}\end{array}$ & $\begin{array}{l}\text { Assay. } \\
++ \text { Xpert }^{(\mathrm{r})}\end{array}$ & $\begin{array}{l}\text { Assay. } \\
++ \text { Xpert }^{(\mathrm{r})}\end{array}$ & $\begin{array}{l}\text { Assay. } \\
++ \text { Xpert }^{(\mathrm{r})}\end{array}$ & $\begin{array}{l}\text { Assay. } \\
++ \text { Xpert }^{(\mathrm{r})}\end{array}$ & $\begin{array}{l}\text { Assay. } \\
++\mathrm{Xpe}\end{array}$ \\
\hline MTB/RIF & MTB/RIF & MTB/RIF & MTB/RIF & MTB/RIF & MTB/RIF & MTB/RIF & MTB/RIF & MTB/ \\
\hline Ultra & Ultra & Ultra & Itra & Itra & Ultra & Ultra & Ultra & Jltra \\
\hline qPCR & qPCR & qPCR & qPCR & ${ }^{\mathrm{CR}}$ & PCR & qPCR & qPCR & PCR \\
\hline assay. & assay. & assay. & assay. & ssay. & ssay. & assay. & ssay. & ssay. \\
\hline SS- & SS- & SS- & SS- & SS- & SS- & SS- & SS- & SS- \\
\hline Greater & Greater & Greater & eater & ater & Gree & Greater & reater & Greate \\
\hline Kruger & Kru & ruger & ruger & er & $\mathrm{ru}$ & (2) & ser & Kruger \\
\hline $\begin{array}{l}\text { Pro- } \\
\text { tected }\end{array}$ & $\begin{array}{l}\text { Pro- } \\
\text { tected }\end{array}$ & $\begin{array}{l}\text { Pro- } \\
\text { tected }\end{array}$ & $\begin{array}{l}\text { Pro- } \\
\text { tected }\end{array}$ & $\begin{array}{l}\text { Pro- } \\
\text { tected }\end{array}$ & $\begin{array}{l}\text { Pro- } \\
\text { tected }\end{array}$ & $\begin{array}{l}\text { Pro- } \\
\text { tected }\end{array}$ & $\begin{array}{l}\text { Pro- } \\
\text { tected }\end{array}$ & $\begin{array}{l}\text { Pro- } \\
\text { tected }\end{array}$ \\
\hline Area & Are & Are & 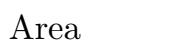 & res & $\operatorname{Ir}$ & Are & Ar & rea \\
\hline GKPA). & (GK & (GK & A). & & & & & 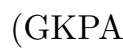 \\
\hline $\begin{array}{l}\text { Pserum } \\
\text { sample }\end{array}$ & $\begin{array}{l}\text { Pserum } \\
\text { sample }\end{array}$ & $\begin{array}{l}\text { Pserum } \\
\text { sample }\end{array}$ & $\begin{array}{l}\text { Pserum } \\
\text { sample }\end{array}$ & $\begin{array}{l}\text { Pserum } \\
\text { sample }\end{array}$ & $\begin{array}{l}\text { Pserum } \\
\text { sample }\end{array}$ & $\begin{array}{l}\text { Pserum } \\
\text { sample }\end{array}$ & $\begin{array}{l}\text { Pserum } \\
\text { sample }\end{array}$ & $\begin{array}{l}\text { Pserum } \\
\text { sample }\end{array}$ \\
\hline was not & was not & was not & was not & was not & was not & was not & was not & vas not \\
\hline avail_- & avail- & & 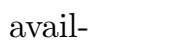 & 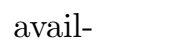 & avail & & ave & ail- \\
\hline able for & able for & e for & e for & le for & able for & able for & able for & able $\mathrm{f}$ \\
\hline & & & & & & & & \\
\hline animal & animal & & & & & & an & animal \\
\hline there- & there- & there- & there- & there- & there- & the & there- & there- \\
\hline fore a & & & & & & & & fore a \\
\hline $\mathrm{DPP}^{(\mathrm{r})}$ & $\mathrm{DPP}^{(\mathrm{r})}$ & $\mathrm{DPP}^{(\mathrm{r})}$ & $\mathrm{DPP}^{(\mathrm{r})}$ & $\mathrm{DPP}^{(\mathrm{r})}$ & $\mathrm{DPP}^{(\mathrm{r})}$ & $\mathrm{DPP}^{(\mathrm{r})}$ & $\mathrm{DPP}^{(\mathrm{r})}$ & $\operatorname{DPP}^{(\mathrm{r})}$ \\
\hline test was & test was & test was & test was & test was & test was & test was & test was & test wi \\
\hline not & not & not & not & not & not & not & not & not \\
\hline done. & done. & done. & done. & done. & done. & done & done. & done. \\
\hline *culture & ${ }^{*}$ culture & ${ }^{*}$ culture & ${ }^{*}$ culture & ${ }^{*}$ culture & ${ }^{*}$ culture & *culture & ${ }^{*}$ culture & $*^{*}$ cultu \\
\hline negative & & & & & & & negative & negat \\
\hline animals & animals & animals & animals & nim & animals & anin & animals & anime \\
\hline did not & did not & did not & did not & did not & did not & did not & did not & $\operatorname{did} n$ \\
\hline require & & require & require & require & require & require & require & requir \\
\hline further & further & further & further & further & further & further & further & further \\
\hline speciation. & speciation. & speciation. & speciation. & speciation. & speciation. & speciation. & speciation. & speci \\
\hline
\end{tabular}

Table 3: Isolate information and spoligotype pattern for the common hippopotamus identified as Mycobacterium bovis positive by mycobacterial culture and speciation in the Greater Kruger Protected Area (GKPA).

\begin{tabular}{llllllll}
\hline $\begin{array}{l}\text { Sample } \\
\text { Number }\end{array}$ & $\begin{array}{l}\text { Sample } \\
\text { Year }\end{array}$ & Species & $\begin{array}{l}\text { Common } \\
\text { Name }\end{array}$ & $\begin{array}{l}\text { Sampling } \\
\text { Location }\end{array}$ & MTBC & $\begin{array}{l}\text { Spoligotype } \\
\text { Pattern }\end{array}$ & $\begin{array}{l}\text { SB } \\
\text { Number }\end{array}$ \\
\hline $19 / 169$ & 2019 & $\begin{array}{l}\text { Hippopotamus } \\
\text { amphibius }\end{array}$ & $\begin{array}{l}\text { Common } \\
\text { Hippopotamus }\end{array}$ & GKPA & M. bovis & ggcgggggcggggggdgogglcgggggg \\
\hline
\end{tabular}




\section{Hosted file}

Table 1.docx available at https://authorea.com/users/344506/articles/471000-implicationsof-interspecies-transmission-and-diagnosis-of-mycobacterium-bovis-infection-in-freeranging-common-hippopotamus-hippopotamus-amphibius

\section{Hosted file}

Table 2.docx available at https://authorea.com/users/344506/articles/471000-implicationsof-interspecies-transmission-and-diagnosis-of-mycobacterium-bovis-infection-in-freeranging-common-hippopotamus-hippopotamus-amphibius

\section{Hosted file}

Table 3.docx available at https://authorea.com/users/344506/articles/471000-implicationsof-interspecies-transmission-and-diagnosis-of-mycobacterium-bovis-infection-in-freeranging-common-hippopotamus-hippopotamus-amphibius 